\title{
Performance of Summer Pearl Millet (Pennisetum glaucum L.) Hybrids under North Gujarat Conditions
}

\author{
R.P. Chaudhari ${ }^{1}$, P.M. Patel ${ }^{2}$, B.M. Patel ${ }^{3}$, Upesh Kumar ${ }^{4 *}$, S.S. Darji ${ }^{5}$ and S.J. Patel ${ }^{4}$ \\ ${ }^{1}$ SMS, Crop Production, KVK, Patna, India \\ ${ }^{2}$ Crop Production, DEE, SDAU, Dantiwada, India \\ ${ }^{3}$ Agronomy, SDAU, Dantiwada, India \\ ${ }^{4} K V K$, Patna, India \\ ${ }^{5}$ SMS, Horticulture, KVK, Patna, India \\ *Corresponding author
}

\section{A B S T R A C T}

Keywords

Pearl millet, Hybrid variety

Article Info

Accepted:

06 December 2017

Available Online:

10 January 2018
An experiment was conducted on plot number C-10, Agronomy Instructional Farm, C. P. College of Agriculture, Sardarkrushinagar Dantiwada Agricultural University, Sardarkrushinagar during summer season of the year 2012 on Loamy Sand soil. Four hybrids viz., GHB 732, GHB 744, GHB 538 and GHB 558 were taken under study. Grain and dry fodder yields were significantly higher in case of hybrid GHB 558 as compared to GHB 744, GHB 538 and GHB 732. Similar response trend was observed in the growth attributes viz., plant height at 60 DAS and harvest, total tillers per plant.

\section{Introduction}

The common name of pearl millet over large part of India is bajra or bajri which is low price food grain crop Pearl millet [Pennisetum glaucum (L.)] belong to Poaceae family. It is one of the most important cereal crops of India and rank $4^{\text {th }}$ in area after rice, wheat and sorghum, which is grown in arid and semi-arid regions. India and Africa together account 93.2 per cent of the total pearl millet production of the world. The share of pearl millet in total food grain production is 10.7 per cent.
Pearl millet is the most widely cultivated cereal crop in India. It is grown on more than $8.39 \mathrm{~m}$ ha with current grain production of 9.15 MT and productivity of $1091 \mathrm{~kg} \mathrm{ha}^{-1}$ during summer season (DES, 2012).

The nutritive values of the pearl millet grains are fairly high with 69.4 per cent carbohydrate, 12.1 per cent protein, 4.3 to 5.0 per cent fat, 2 to 7 per cent mineral matter and 2.4 per cent sugar. It is also rich in vitamins, thiamine and riboflavin contents and imparts substantial energy to the body with easy digestibility (Pal et al., 1996). 
The major pearl millet growing states of India are Rajasthan, Maharashtra, Gujarat, Uttar Pradesh and Haryana which account for more than $90 \%$ of pearl millet acreage in country. Pearl millet can easily provide economical grain yield (600-700 $\left.\mathrm{kg} \mathrm{ha}^{-1}\right)$ under marginal and low management conditions, with the additional ability to produce a grain yield of 4000-5000 kg ha ${ }^{-1}$ when hybrids (80-85 days maturity) are grown as a summer crop under irrigated and high fertility conditions.

The area under summer pearl millet was 3829 hundred hectares with an annual production of $941700 \mathrm{MT}$ and productivity of $2459 \mathrm{~kg} \mathrm{ha}^{-1}$ in the Gujarat state during 2011 (Anon., 2011a).

Adoption of high yielding short duration varieties which plays important role in the maximization of pearl millet production per unit area per unit time. Short duration and high yielding varieties of pearl millet can enhance the production. Screening of hybrid varieties which are appropriate to that particular climatic condition can help in boosting the production of pearl millet.

\section{Materials and Methods}

The field experiment was conducted on plot No. C-10 during summer season of 2012 at Agronomy Instructional Farm, Chimanbhai Patel College of Agriculture, Sardarkrushinagar Dantiwada Agricultural University, Sardarkrushinagar. The summer season (March-June) is generally hot and dry. Occurrence of storms and winds with very high velocity is very common during summer season. May is the hottest month of the year. It was observed that the soil of experimental plot was loamy sand in texture. The soil was low in organic carbon and available nitrogen, medium in available phosphorous and potash. The soil was free from salinity/sodicity hazard.
The pearl millet hybrids GHB 732, GHB 744, GHB 538, and GHB 558 were selected for the present investigation. The pearl millet hybrids have been evolved at Main Millet Research Station, Junagadh Agricultural University, Jamnagar and released for commercial cultivation. During the study, following parameter was recorded in scientific manner.

\section{Growth attributes}

\section{Plant population}

The number of plants per meter row length from each net plot were counted after thinning and recorded per meter row length.

\section{Plant height (cm)}

Plant height was measured periodically from base of the plant (ground level) to the tip of the main shoot at 30 and 60 DAS as well as maturity. The mean height of five sample plants was worked out and recorded for each plot according to the treatment.

\section{Tillers per plant}

Tillers per plant of five randomly selected plants in each net plot was counted and recorded. The mean number of tillers per plant for each treatment plot was worked out and recorded for respective treatment.

\section{Yield attributes and yield}

The details of the yield attributing recorded during the period of investigation are described below

\section{Effective tillers per plant}

The tillers producing ear heads bearing grains were counted from the previously selected five plants and the mean value was worked out and recorded for respective treatment plot. 


\section{Length of ear head}

The length from the base to the apex of the ear head of main ear head of the five tagged plants for all the plots were measured in $\mathrm{cm}$. The mean value of five plants was worked out and recorded for respective treatment.

\section{Girth of ear head}

The ear heads used for measurement of length were also used for this parameter. Top, middle and bottom of ear head thickness was measured in $\mathrm{cm}$ by Vernier calliper and mean girth was computed for each ear head. The average girth of ear head was worked out for each treatment plot and recorded under respective treatment.

\section{0-grain weight}

The composite sample of grains was collected from the grain yield of each net plot, from which 1000 grains were counted and their weight was recorded for respective treatment.

\section{Grain yield $\left(\mathrm{kg} \mathrm{ha}^{-1}\right)$}

Ear heads of each net plot were threshed and cleaned separately and recorded for each respective treatment. Grain yield of five tagged plants was also added to respective net plot yield and finally net plot yield was worked out for respective treatment.

\section{Dry fodder yield $\left(\mathrm{kg} \mathrm{ha}^{-1}\right)$}

After nipping the ear heads from net plot, the plant was cut and allowed to sundry for 8-10 days in respective treatment plot and then it was weighed repeatedly till constant weight obtained.

Dry fodder yield was calculated adding dry fodder yield of respective five tagged plants for treatment plot.

\section{Results and Discussion}

Meteorological data presented in Table 1 and Figure 1 showed that the weather parameters during the crop season were within the optimum limits, and were found conducive for normal growth and development of the crop. The data indicated that the maximum temperature ranged between 23.8 to $40.4^{\circ} \mathrm{C}$, while minimum temperature ranged between 5.3 to $26.7^{\circ} \mathrm{C}$ during the period of experimentation. The relative humidity at morning ranged between 57 to 87 per cent and at evening ranged between 15 to 45 per cent and the sunshine hours ranged between 5.3 to 10.5 hours which were found normal (Fig. 1). No severe incidence of insect-pests was observed in the year under study. The initial and final plant populations were observed to be uniform.

Hybrids had non-significant effect on plant height of pearl millet recorded at 30 DAS (Table 2). Plant height significantly with 60 DAS and at harvest in hybrids, hybrid GHB 558 recorded higher plant height than those recorded GHB 732, GHB 538 and GHB 744.

The difference in plant height might be due to genetically make up of plant itself, which is governed by vegetative growth of crop as it played vital role in accelerating all the physiological processes in plants. These findings are in accordance with those reported by Singh and Singh (1971), Patel (1976), Patel (1981), Bagada and Patel (1983), Patel (1988), Dalshaniya (1993) and Patel (1995).

In general, differences in total tillers per plant were observed remarkably. Hybrid GHB 558 recorded more total tillers per plant. This increase was attributed to the genetical characteristics of hybrid GHB 558. Similar findings were also recorded by Singh and Singh (1971), Patel (1981), Bagada and Patel (1983), Dalshaniya (1993) 
Characteristics of pearl millet hybrids

\begin{tabular}{|c|c|c|c|c|c|}
\hline \multirow{2}{*}{ Sr.No. } & \multirow{2}{*}{ Characters } & \multicolumn{4}{|c|}{ Pearl millet hybrids } \\
\hline & & GHB 732 & GHB 744 & GHB 538 & GHB 558 \\
\hline \multirow[t]{3}{*}{1.} & Parents : & & & & \\
\hline & Female & $96222 \mathrm{~A}$ & $98444 \mathrm{~A}$ & $95444 \mathrm{~A}$ & 94555 \\
\hline & Male & J 2340 & J 2340 & J 2340 & J 2290 \\
\hline 2. & Plant height $(\mathrm{cm})$ & $190-195$ & $180-190$ & $155-165$ & $200-210$ \\
\hline 3. & $\begin{array}{l}\text { Effective tillers per } \\
\text { plant }\end{array}$ & $3-4$ & $3-4$ & $4-6$ & $3-5$ \\
\hline 4. & Maturity days & $80-85$ & $76-80$ & $75-78$ & $80-85$ \\
\hline 5. & $\begin{array}{l}\text { Reaction to Downey } \\
\text { mildew disease }\end{array}$ & Resistant & Resistant & Resistant & Resistant \\
\hline 6. & $\begin{array}{l}\text { Average yield } \\
\left(\mathrm{kg} \mathrm{ha}^{-1}\right)\end{array}$ & 5037 & 2857 & 4389 & 4449 \\
\hline
\end{tabular}

Table.1 Meteorological data recorded for the period of experiment at Sardarkrushinagar during 2012

\begin{tabular}{|c|c|c|c|c|c|c|c|c|c|}
\hline \multirow{2}{*}{$\begin{array}{l}\text { Month } \\
\text { and } \\
\text { Year }\end{array}$} & \multirow[t]{2}{*}{$\begin{array}{l}\text { Std. } \\
\text { Week }\end{array}$} & \multirow[t]{2}{*}{ Dates } & \multicolumn{2}{|c|}{$\begin{array}{l}\text { Temperature } \\
\left({ }^{\circ} \mathrm{C}\right)\end{array}$} & \multicolumn{2}{|c|}{$\begin{array}{c}\text { Relative } \\
\text { Humidity }(\%)\end{array}$} & \multirow{2}{*}{$\begin{array}{c}\text { Wind } \\
\text { velocity } \\
\left(\mathrm{km} \mathrm{hr}^{-1}\right)\end{array}$} & \multirow{2}{*}{$\begin{array}{c}\text { Bright } \\
\text { sunshine } \\
\text { hours }\end{array}$} & \multirow[t]{2}{*}{$\begin{array}{l}\text { Rainfall } \\
\text { (mm) }\end{array}$} \\
\hline & & & Max. & Min. & Morn. & Even. & & & \\
\hline \multirow{4}{*}{$\begin{array}{l}\text { Feb. } \\
2012\end{array}$} & 05 & $29-4$ & 26.6 & 5.9 & 71 & 31 & 6.6 & 9.6 & 0.0 \\
\hline & 06 & $5-11$ & 23.8 & 5.9 & 57 & 20 & 11.9 & 9.8 & 0.0 \\
\hline & 07 & $12-18$ & 27.6 & 10.9 & 60 & 21 & 9.0 & 9.4 & 0.0 \\
\hline & 08 & $19-25$ & 30.4 & 11.6 & 71 & 19 & 5.3 & 9.7 & 0.0 \\
\hline \multirow{5}{*}{$\begin{array}{c}\text { March } \\
2012\end{array}$} & 09 & $26-3$ & 30.7 & 11.7 & 70 & 20 & 7.8 & 10.2 & 0.0 \\
\hline & 10 & $4-10$ & 30.7 & 12.2 & 72 & 18 & 6.1 & 9.1 & 0.0 \\
\hline & 11 & $11-17$ & 32.8 & 12.3 & 62 & 15 & 4.7 & 9.6 & 0.0 \\
\hline & 12 & $18-24$ & 35.8 & 15.6 & 66 & 17 & 4.3 & 8.0 & 0.0 \\
\hline & 13 & $25-31$ & 38.4 & 17.7 & 73 & 22 & 3.5 & 8.6 & 0.0 \\
\hline \multirow{4}{*}{$\begin{array}{c}\text { April } \\
2012\end{array}$} & 14 & $1-7$ & 40.4 & 21.1 & 62 & 16 & 3.9 & 9.0 & 0.0 \\
\hline & 15 & $8-14$ & 38.8 & 21.1 & 70 & 24 & 6.4 & 9.0 & 0.0 \\
\hline & 16 & $15-21$ & 37.1 & 21.7 & 66 & 24 & 5.7 & 8.9 & 0.0 \\
\hline & 17 & $22-28$ & 36.6 & 21.5 & 64 & 27 & 4.6 & 10.5 & 0.0 \\
\hline \multirow{4}{*}{$\begin{array}{l}\text { May } \\
2012\end{array}$} & 18 & $29-5$ & 39.3 & 22.2 & 63 & 23 & 5.2 & 10.4 & 0.0 \\
\hline & 19 & $6-12$ & 38.5 & 24.7 & 78 & 35 & 6.0 & 10.2 & 0.0 \\
\hline & 20 & 13-19 & 39.0 & 25.5 & 78 & 38 & 7.4 & 9.9 & 0.0 \\
\hline & 21 & $20-26$ & 40.2 & 24.9 & 86 & 32 & 7.3 & 10.5 & 0.0 \\
\hline \multirow{4}{*}{$\begin{array}{l}\text { June } \\
2012\end{array}$} & 22 & $27-2$ & 40.2 & 24.9 & 77 & 36 & 8.8 & 8.7 & 0.0 \\
\hline & 23 & $3-9$ & 38.6 & 26.5 & 74 & 38 & 12.8 & 5.3 & 0.0 \\
\hline & 24 & $10-16$ & 38.3 & 26.3 & 78 & 45 & 8.2 & 8.8 & 38.0 \\
\hline & 25 & $17-23$ & 38.0 & 26.7 & 80 & 42 & 14.2 & 7.7 & 0.0 \\
\hline
\end{tabular}


Table.2 Plant height at 30, 60 DAS and at harvest $(\mathrm{cm})$ as influenced by different hybrids

\begin{tabular}{|c|c|c|c|}
\hline \multirow[t]{2}{*}{ Treatments } & \multicolumn{3}{|c|}{ Plant height (cm) } \\
\hline & At 30 DAS & At 60 DAS & At harvest \\
\hline $\mathrm{V}_{1}: \mathrm{GHB} 732$ & 69.82 & 142.5 & 189.3 \\
\hline $\mathrm{V}_{2}:$ GHB 744 & 69.01 & 138.3 & 185.3 \\
\hline $\mathrm{V}_{3}: \mathrm{GHB} 538$ & 63.68 & 132.0 & 161.6 \\
\hline $\mathrm{V}_{4}:$ GHB 558 & 69.97 & 146.4 & 192.9 \\
\hline S.Em. \pm & 1.74 & 1.60 & 1.79 \\
\hline C. D. at $5 \%$ & NS & 4.65 & 5.20 \\
\hline C. V. $(\%)$ & 8.85 & 3.97 & 3.41 \\
\hline
\end{tabular}

Table.3 Tillers per plant at harvest as influenced by different hybrids

\begin{tabular}{|c|c|c|}
\hline Treatments & \multicolumn{2}{|c|}{ Tillers per plant at harvest } \\
\hline & Effective tillers & Total tillers \\
\hline $\mathrm{V}_{1}:$ GHB 732 & 4.41 & 5.62 \\
\hline $\mathrm{V}_{2}: \mathrm{GHB} 744$ & 4.09 & 5.13 \\
\hline $\mathrm{V}_{3}:$ GHB 538 & 4.29 & 5.38 \\
\hline $\mathrm{V}_{4}:$ GHB 558 & 4.63 & 5.87 \\
\hline S.Em.t & 0.093 & 0.113 \\
\hline C. D. at $5 \%$ & 0.27 & 0.32 \\
\hline C. V. $(\%)$ & 7.42 & 7.13 \\
\hline
\end{tabular}

Table.4 Length and girth of ear head of pearl millet at harvest as influenced by different hybrids

\begin{tabular}{|c|} 
Treatments \\
\hline $\mathrm{V}_{1}:$ GHB 732 \\
\hline $\mathrm{V}_{2}:$ GHB 744 \\
\hline $\mathrm{V}_{3}$ :GHB 538 \\
\hline $\mathrm{V}_{4}$ :GHB 558 \\
\hline S.Em. \pm \\
\hline C. D. at $5 \%$ \\
C. V. $\%$ )
\end{tabular}

\begin{tabular}{|c|}
\hline Length of ear head (cm) \\
\hline 23.70 \\
\hline 22.04 \\
\hline 22.62 \\
\hline 26.09 \\
0.540 \\
\hline 1.56 \\
7.92 \\
\hline
\end{tabular}

Girth of ear head (cm)

\begin{tabular}{|c|}
\hline 10.53 \\
\hline 9.83 \\
\hline 10.32 \\
\hline 10.79 \\
\hline 0.223 \\
\hline 0.64 \\
\hline 7.45 \\
\hline
\end{tabular}


Table.5 Grain weight per plant (g) and 1000-grain weight (g) of pearl millet as influenced by different hybrids

\begin{tabular}{|c|}
\hline Treatments \\
\hline$V_{1}:$ GHB 732 \\
\hline$V_{2}:$ GHB 744 \\
\hline$V_{3}:$ GHB 538 \\
\hline$V_{4}:$ GHB 558 \\
\hline S.Em. \pm \\
\hline C. D. at $5 \%$ \\
\hline C. V. $(\%)$ \\
\hline
\end{tabular}

\section{Grain weight per plant (g) at harvest}

\begin{tabular}{|c|}
\hline 48.06 \\
\hline 42.82 \\
\hline 45.98 \\
\hline 52.25 \\
\hline 1.19 \\
\hline 3.47 \\
\hline 8.77 \\
\hline
\end{tabular}

(1000-grain weight)

\begin{tabular}{|c|}
\hline 9.55 \\
\hline 9.15 \\
\hline 9.40 \\
\hline 9.93 \\
\hline 0.156 \\
\hline 0.454 \\
\hline 5.71 \\
\hline
\end{tabular}

Table.6 Grain yield and straw yield of pearl millet as influenced by different hybrids

\begin{tabular}{|c|}
\hline Treatments \\
\hline $\mathrm{V}_{1}:$ GHB 732 \\
\hline $\mathrm{V}_{2}:$ GHB 744 \\
\hline $\mathrm{V}_{3}:$ GHB 538 \\
\hline $\mathrm{V}_{4}:$ GHB 558 \\
\hline S.Em. \pm \\
\hline C. D. at $5 \%$ \\
\hline C. V. $(\%)$ \\
\hline
\end{tabular}

\begin{tabular}{|c|}
\hline Grain yield $\left(\mathrm{kg} \mathrm{ha}^{-1}\right)$ \\
\hline 4676 \\
\hline 3946 \\
\hline 4276 \\
\hline 4969 \\
\hline 102 \\
\hline 295 \\
\hline 7.89 \\
\hline
\end{tabular}

\begin{tabular}{|c|}
\hline Dry fodder yield $\left(\mathrm{kg} \mathrm{ha}^{-1}\right)$ \\
\hline 9154 \\
\hline 7894 \\
\hline 8575 \\
\hline 9720 \\
\hline 196 \\
\hline 569 \\
\hline 7.68 \\
\hline
\end{tabular}

Fig.1 Meteorological data recorded for the period of experiment at Sardarkrushinagar during 2012

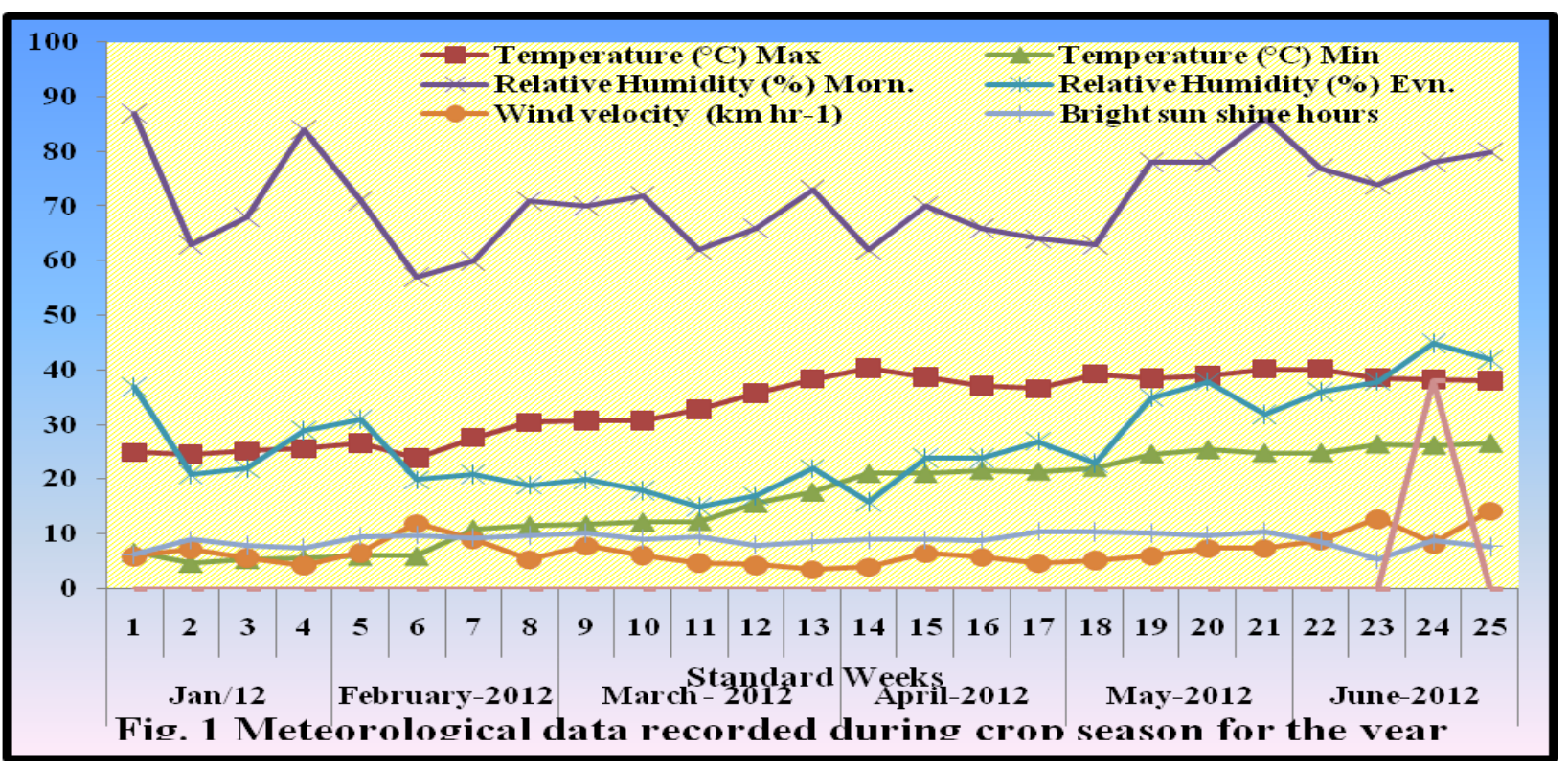


Differential observations were recorded in case of effective tillers per plant among different hybrids. Hybrid GHB 558 recorded higher effective tillers per plant than those under GHB 732, GHB 538 and GHB 744 hybrids. This increase was attributed to the genetically constituent of hybrid GHB 558 (Table 3). Similar findings were also recorded by Patel (1976), Patel (1988), and Patel (1995).

The data presented in Table 4 showed that hybrids have their individual effects on length of ear head. Hybrid GHB 558 recorded numerically longer ear heads than those under GHB 732, GHB 538 and GHB 744 hybrids. The less differences noted were due to genetical make-up of the hybrid. The results are in agreement with those reported by Jadav and Patel (1977), Varma (1986), Patel (1988), Dalshaniya

The data presented in Table 4 showed that hybrids have their individual effects on girth of ear head. Hybrid GHB 558 recorded remarkably higher girth of ear head than those under GHB 732, GHB 538 and GHB 744 hybrids. The differences noted were due to genetical make-up of the hybrids. Similar results were also reported by Bagada and Patel (1983) and Dalshaniya (1993).

From the data presented on 1000-grain weight, hybrid GHB 558 recorded higher 1000-grain weight than those under GHB 732, GHB 538 and GHB 744 hybrids. This might be attributed to bolder grain produced by GHB 558 hybrid. These finding was substantiated Patel (1981), Bagada and Patel (1983), Varma (1986),

Data pertaining to grain yield per plant and grain yield (Table 5) as influenced by different hybrids showed significant superiority of GHB 558 over that of GHB 732, GHB 538 and GHB 744 hybrids. These increases in case of grain yield per plant were attributed to higher values for length and girth of ear head recorded under GHB 558. The increase in grain yield was also due to higher values for all the yield attributes viz., effective tillers per plant, length and girth of ear head and grain weight per plant recorded under GHB 558. Results pertaining to grain yield per plant are in agreement with those reported by Bagada and Patel (1983) and in case of grain yield reported by Singh and Singh (1971), Dalshaniya (1993) and Patel (1995).

From the data of dry fodder yield (Table 6) as influenced by different hybrids, it appeared that GHB 558 surpassed GHB 732, GHB 538 and GHB 744 hybrids, the increase in dry fodder yield of GHB 558 was owing to significant increase in plant height (Table 2). The present results are akin to those obtained Patel (1995).

From the foregoing discussion, it is concluded that pearl millet hybrid GHB 558 should be grown for securing maximum grain yield and net realization with higher BCR. Pearl millet crop should be sown on $2^{\text {nd }}$ March for maximum grain and dry fodder yields as well as net realization and BCR under North Gujarat conditions.

\section{References}

Anonymous 2011a. District wise area, production and yield of important food and non-food crops in Gujarat state for the year of 2010-11 to 2011-12. Directorate of Agriculture, Gujarat State, Gandhinagar.

Bagada, J.R. and Patel, J.C. 1983. Comparative yield potential of pearl millet hybrids to varying levels of nitrogen. Indian J. Agron., 29: 309-310.

Dalshaniya, J.R. 1993. Response of pearl millet hybrids to varying levels of $\mathrm{N}$ and P. M.Sc. (Agri) Thesis submitted to 
Gujarat Agricultural University, Sardarkrushinagar.

DES 2012. Area and production of principal crops in India. Directorate of economics and statistics, Department of Agriculture and Co-operation, Ministry of Agriculture. Government of India, New Delhi.

Jadav, K.V. and Patel, J.C. 1977. Response of pearl millet hybrids to nitrogen and phosphorus. G.A.U. Res. J., 3 (1): 4648.

Pal, M., Deka, J. and Raj, R.K. 1996. Fundamentals of cereals crop production. Tata McGraw Hill Publishing Co. Ltd., New Delhi.

Patel, A.M. 1981. Influence of nitrogen and zinc levels on the performance of hybrids varieties of bajra (pennisetum typhoides) M.Sc. (Agri.) Thesis submitted to Gujarat Agricultural University, Sardarkrushinagar.

Patel, H.S. 1976. Response of pearl millet hybrids to plant densities and nitrogen levels under irrigated condition in summer season. M.Sc. (Agri.) Thesis submitted to Gujarat Agricultural University, Sardarkrushinagar.

Patel, J.J. 1995. Response of summer pearl millet cultivars to FYM and inorganic fertilizers under middle Gujarat conditions. M.Sc. (Agri.)

Patel, V.K. 1988. Performance of pearl millet hybrids in summer at different inter and intra-row spacings. M.Sc. (Agri.) Thesis Gujarat Agricultural University, Sardarkrushinagar.

Singh, K. and Singh, J. 1971. The effect of graded doses of nitrogen on the growth and yield of Bajra hybrids grown under irrigated condition. Indian J. Agric. Sci., 5 (1): 58-60.

Varma, H.N. 1986. Effect of levels of nitrogen and phosphorus on the yield of hybrid varieties of pearl millet under North Gujarat conditions. M.Sc. (Agri.) Thesis submitted to Gujarat Agricultural University, Sardarkrushinagar.

\section{How to cite this article:}

Chaudhari, R.P., P.M. Patel, B.M. Patel, Upesh Kumar, S.S. Darji and Patel, S.J. 2018. Performance of Summer Pearl Millet (Pennisetum glaucum L.) Hybrids under North Gujarat Conditions. Int.J.Curr.Microbiol.App.Sci. 7(01): 637-644.

doi: https://doi.org/10.20546/ijcmas.2018.701.077 